International Journal of Current Advanced Research

ISSN: O: 2319-6475, ISSN: P: 2319 - 6505, Impact Factor: SJIF: 5.995

Available Online at www.journalijcar.org

Volume 6; Issue 4; April 2017; Page No. 3272-3274

DOI: http://dx.doi.org/10.24327/ijcar.2017.3274.0244

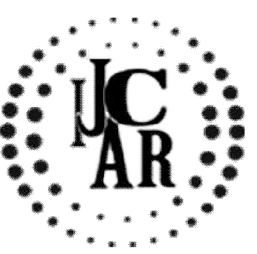

Review Article

\title{
POLYAMIDE AS A DENTURE BASE MATERIAL- A REVIEW
}

\author{
Nivedha Srinivasan and Dhanraj G
}

Saveetha Dental College

\begin{tabular}{l}
\hline A R T I C L E I N F O \\
\hline Article History: \\
Received $19^{\text {th }}$ January, 2017 \\
Received in revised form $24^{\text {th }}$ February, 2017 \\
Accepted $22^{\text {nd }}$ March, 2017 \\
Published online $28^{\text {th }}$ April, 2017 \\
\end{tabular}

Key words:

Polyamide, Thermoplastic

\begin{abstract}
A B S T T R A C T
Aim: the aim of the study is to understand the properties of polyamide as a denture base material. Objective: The purpose of this article was to review the bicompatibility, physical, and machanical properties of the polyamide denture base materials Background: Polyamide resin was proposed as a denture base material in the 1950s. Nylon is a generic name for certain types of thermoplastic polymers belonging to the class known as polymides. Nylon is a crystalline polymer and this crystalline effect accounts for the lack of solubility of nylon in solvents, as well as high heat resistance and high strength ductility. On the other side, it is reported that this material has several problems such as water sorption, surface roughness, bacterial contamination,, color deterioration and difficulty in polishing. Reason: Since there is a very limited knowledge about polyamide's clinical performance, strict and careful follow up evaluation of the patients rehabilitated with polyamide prosthesis is required.
\end{abstract}

Copyright $\bigcirc 2017$ Nivedha Srinivasan and Dhanraj G. This is an open access article distributed under the Creative Commons Attribution License, which permits unrestricted use, distribution, and reproduction in any medium, provided the original work is properly cited.

\section{INTRODUCTION}

Polyamide resin was proposed as denture base material in 1950s. Nylon is the generic name of certain types of thermoplastic polymers belonging to the class known as polyamides. Nylon is a crystalline polymer and this crystalline effect accounts for the lack of solubility of nylon in solvents, as well as high heat resistance and high strength coupled with ductility [1]. T hermoplastic acrylic has been used in dentistry for many years in the form of temporary crowns and thermal polymerized as baseplate material for partial and complete dentures. Thermal polymerized PMMA demonstrates high porosity, high water absorption, volumetric changes and residual monomer. They have poor impact resistance, tensile and flexural strength for a variety of applications. Thus, improvised thermoplastic nylon can be a useful alternative to polymethylmethacrylate in special circumstances where higher flexibility, higher resistance to flexural fatigue, higher impact strength is required [2]. These often lead to denture failure during chewing or when fall out of the patient's hand. In order to enhance some properties of PMMA, various efforts have been taken including addition of metal wires or plates, fibers, [3-6] metal inserts, [7] and modification of chemical structure. In recent years, nylon polymer has attracted attention as a denture base materials. On the other side, it is reported that this material has several problems such

*Corresponding author: Nivedha Srinivasan

Saveetha Dental College as water sorption, surface roughness, bacterial contamination, warpage, color deterioration, and difficulty in polishing.[8] The present study is a literature review to appraise some physical, mechanical and clinical properties of nylon/ polyamide denture base materials.

\section{DISCUSSION}

\section{Physical properties of polyamide}

PMMA is a strong and lightweight material. It has a density of $1.17-1.20 \mathrm{~g} / \mathrm{cm}^{3},[9,10]$ which is less than half that of glass[9]. It also has good impact strength, higher than both glass and polystyrene; however, PMMA's impact strength is still significantly lower than polycarbonate and some engineered polymers. PMMA ignites at $460^{\circ} \mathrm{C}\left(860^{\circ} \mathrm{F}\right)$ and burns, forming carbon dioxide, water, carbon monoxide and low-molecular-weight compounds, including formaldehyde [11].

PMMA transmits up to $92 \%$ of visible light (3 mm thickness), and gives a reflection of about $4 \%$ from each of its surfaces due to its refractive index $(1.4905$ at $589.3 \mathrm{~nm}) .{ }^{[3]} \mathrm{It}$ filters ultraviolet (UV) light at wavelengths below about $300 \mathrm{~nm}$ (similar to ordinary window glass

\section{Hardness}

Ucar et al. in 2012[13] compared the hardness of a polyamide based denture material (Deflex) with another injectionmolded PMMA base material and a conventional compression-molded PMMA. The results of the study on Deflex specimens were found to be much lower than other 
materials and that material was not as hard as other materials. In the study by Shah et al. (2014) [14] PMMA demonstrated higher hardness values when compared with flexible resin. This result might be attributed to a high monomer-polymer ratio, the attachment of this material, and the presence of methyl-methacrylate monomer. Moreover, cross-linking agents may exist in the material. Flexible resin demonstrated lower hardness values and also possessed lower amounts of cross-linking agents, indicating that cross-linking agent may affect surface hardness.

\section{Surface Roughness}

A rougher surface can cause discomfort to patients and also discoloration of the prosthesis; it may contribute to microbial colonization and biofilm formation. Abuzar et al. in 2010[15] evaluated the surface roughness of a polyamide denture base material (Flexiplast) in comparison with PMMA (Vertex RS), and found that polyamide specimens produced a rougher surface than PMMA, both before and after the polishing process. Similar to polymethacrylate resin materials, [16] the conventional polishing technique provided a polyamide surface smoothness, well within the clinically acceptable standard. The same results were found in another study done by Kawara et al. in 2014[17] who evaluated the surface roughness of four thermoplastic (polyamide: Valplast, Lucitone FRS, polyethylene terephthalate: EstheShot, and polyester: EstheShot Bright) and two conventional acrylic (Heat-polymerizing: Urban, and Pour type auto-polymerizing: Pro-Cast DSP) denture bases by using scratch test. The results showed that the surface of thermoplastic denture base resins was easily damaged compared with polymethyl methacrylate.

\section{Mechanical Properties}

Polymethyl methacrylate (PMMA) resins are the most commonly used denture materials; however, they do not have a high flexural strength (FS). This study aimed to compare the mechanical properties of a polyamide-based, injection-molded denture material (Deflex) with another injection-molded PMMA base material (SR-Ivocap) and a conventional compression-molded PMMA (Meliodent). Ucar Y suggested that While polyamide denture material produced good fracture resistance, its modulus is not yet sufficiently high to be equal to standard PMMA materials [18].

Hamanaka et al. in 2011,[19] compared some mechanical properties of two polyamides (Nylon 12 and Nylon PACM12), one polyethylene terephthalate and one polycarbonate with a conventional heat-polymerized polymethyl methacrylate (PMMA). They showed that the two polyamides had the lowest values of flexural strength at proportional limit as well as the lowest elastic moduli between denture base resins. They also found that Charpy impact strength was the highest for Nylon PACM12, while Nylon 12 had low impact strength. This study demonstrated that the mechanical properties of injection-molded thermoplastic denture bases differ from each other; hence, the clinicians should be well aware of these properties in order to choose the most suitable one for an RPD without metal clasps that is suitable for each patient.

\section{Biocompatibility}

For biocompatible full dentures one may choose monomerfree thermoplastic acrylic resin. The prosthetic solution of partial edentations with the help of metal-free removable partial dentures represents a modern alternative solution to classical framework dentures, having the advantage of being lightweight, flexible and much more comfortable for the patient. Superflexible polyamide resin is especially indicated for retentive dental fields, which would normally create problems with the insertion and disinsertion of removable partial dentures [20-23]. Dentures made of PMMA, can be color-matched to the patient's teeth \& gum tissue. PMMA is also used in the production of ocular prostheses, such as the osteo-odonto-keratoprosthesis.

\section{Chemical Properties}

In the study carried out by Takabayashi in 2010,[24] water sorption of two of the tested polyamide materials (Valplast and Flexite Supreme) met the ISO standard (32 $\mu \mathrm{g} / \mathrm{mm}[25])$, but Lucitone FRS revealed the highest water sorption due to the greater degree of hydrophilic characteristics supported by the contact angle measurements. It is thought that the higher the amide group concentration, the greater the water sorption. Therefore, it has been suggested that the amide group concentration, in the polyamide type denture base materials, could be adjusted to a level as low as that in popular industrial materials such as nylon 6 or 66.[24] On the other hand, in another study which was done by Shah et al. in 2014, the sorption and solubility of heat-cured polymethyl methacrylate denture base resin and flexible denture base resin were compared and it was found that heat-cured PMMA had more sorption and solubility values than flexible (thermoplastic polyamide nylon) resin.[26] The study suggested that since the contact angle between the flexible resin and water was high with low surface free energy, their water repellency was also high, and these all resulted in lower water sorption values. Likewise, it was mentioned that there was a strong hydrogen bonding between amide groups and a reduction in attachment areas for water molecules; therefore, the amount of water sorption in flexible resin was lower than conventional PMMA. The higher residual monomer contents were mentioned as a cause for the higher solubility level in PMMA [26].

\section{Cytotoxic evaluation of polyamide}

There are several studies in regard to cytotoxicity of denture base materials. [27-30] It has been reported that the acrylic resins used for the fabrication of denture bases have displayed various degrees of in vitro cytotoxicity and in vivo allergic responses, which have been probably caused by non-reacting components that remain after the polymerization process.[31] Nevertheless, studies about cytotoxic effect of polyamides are very limited. Uzun et al.[32] investigated the long-term cytotoxic response of an injection-molded polyamide (Deflex) and heat- and cold-cured PMMA resins. According to the results of their study, all materials had a similar toxic effect in the short term and all tested materials reached the highest levels of toxicity after 8 weeks of their aging time. In their study, polyamide specimens had a comparable toxicity profile with the conventional PMMA denture base materials.

\section{CONCLUSION}

The dentists today have to meet growing demands for prosthetic rehabilitation due to population aging and higher requirements on the quality of life. That means higher demands on the functional reliability of dental appliances, their aesthetical and biological properties. 
Thermoplastic resins have been used in dentistry for many years. During that time the applications have continued to grow and the interest in these materials by both the profession and the public have increased. The materials have superior properties and characteristics and provide excellent esthetic and biocompatible treatment options. With the development of new properties, there are certain to be additional new applications for thermoplastic resin in the future, to help patients with damaged or missing teeth.

\section{References}

1. Schoonover IC: Some properties of two types of resins used for dentures: Jour A.D.A \& D. Cos, Vol 25, September 1938: 1487-1500.

2. Marei MK. Reinforcement of denture base resin with glass fillers. J Prosthodont. 1999; 8: 18-26

3. Doğan OM, Bolayir G, Keskin S, Doğan A, Bek B, Boztuğ A. The effect of esthetic fibers on impact resistance of a conventional heat-cured denture base resin. Dent Mater J. 2007; 26: 232-239.

4. John J, Gangadhar SA, Shah I. Flexural strength of heat-polymerized polymethyl methacrylate denture resin reinforced with glass, aramid, or nylon fibers. $J$ Prosthet Dent. 2001; 86: 424-427.

5. . Vojdani M, Khaledi AAR. Transverse Strength of Reinforced Denture Base Resin with Metal Wire and E-Glass Fibers. J Dent Tehran Univ Med Scien. 2006; 3: 167-172.

6. Vojdani M, Bagheri R, Khaledi AAR. Effects of aluminum oxide addition on the flexural strength, surface hardness, and roughness of heat-polymerized acrylic resin. Journal of Dental Sciences. 2012; 7: 238244.

7. Yunus N, Rashid AA, Azmi LL, Abu Hassan MI. Some flexural properties of a nylon denture base polymer. J Oral Rehabil. 2005; 32: 65-71

8. Polymethylmethacrylate (PMMA, Acrylic). Makeitfrom.com. Retrieved 2015-03-23.

9. DATA TABLE FOR: Polymers: Commodity Polymers: PMMA. Matbase.com. Retrieved 2012-0509.

10. Zeng, W. R.; Li, S. F.; Chow, W. K. (2002). "Preliminary Studies on Burning Behavior of Polymethylmethacrylate (PMMA)". Journal of Fire Sciences. 20 (4): 297-317

11. Refractive index and related constants- Poly (methyl methacrylate) (PMMA, Acrylic glass). Refractiveindex.info. Retrieved 2014-10-27.

12. Ucar Y, Akova T, Aysan I. Mechanical properties of polyamide versus different PMMA denture base materials. J Prosthodont. 2012; 21: 173-176

13. S hah J, Bulbule N, Kulkarni S, Shah R, Kakade D. Comparative Evaluation of Sorption, Solubility and Micro-hardness of Heat Cure Polymethylmethacrylate Denture Base Resin \& Flexible Denture Base Resin. $J$ Clin Diagn Res. 2014; 8: ZF01-ZF04.

14. Abuzar MA, Bellur S, Duong N, Kim BB, Lu P, Palfreyman $\mathrm{N}$, et al. Evaluating surface roughness of a poly-amide denture base material in comparison with poly(methyl methacrylate) J Oral Sci. 2010; 52: 577581.
15. 47. Bahrani F, Safari A, Vojdani M, Karampoor G. Comparison of hardness and surface roughness of two denture bases polymerized by different methods. World J Dent. 2012; 3: 171-175.

16. 48. Kawara M, Iwata Y, Iwasaki M, Komoda Y, Iida T, Asano $\mathrm{T}$, et al. Scratch test of thermoplastic denture base resins for non-metal clasp dentures. $J$ Prosthodont Res. 2014; 58: 35-40.

17. Ucar $\mathrm{Y}^{1}$, Akova T, Aysan I; Mechanical properties of polyamide versus different PMMA denture base materials; J Prosthodont. 2012 Apr; 21(3):173-6.

18. Hamanaka I, Takahashi Y, Shimizu H. Mechanical properties of injection-molded thermoplastic denture base resins. Acta Odontol Scand. 2011; 69: 75-79.

19. Ardelean, L., Borpun, C., Motoc M., Mat. Plast., 44, no. 4,2007 , p. 345

20. Ardelean, L., Borpun, C., Motoc M., Rusu L., Motoc A., Mat. Plast., 45, no. 2, 2008, p. 214

21. Bortun, C., Lakatos, S., Sandu, L., Negrutiu, M., Ardelean, L., T.M.J, 56, nr.1, 2006, p.80

22. Negrupiu, M., Sinescu, C., Românu, M., POP, D., Lakatos, S., T.M.J, 55, nr.3, 2005, p.295

23. Takabayashi Y. Characteristics of denture thermoplastic resins for non-metal clasp dentures. Dent Mater J. 2010; 29: 353-361.

24. Athar Z, Juszczyk AS, Radford DR, Clark RK. Effect of curing cycles on the mechanical properties of heat cured acrylic resins. Eur $J$ Prosthodont Restor Dent. 2009; 17: 58-60

25. Shah J, Bulbule N, Kulkarni S, Shah R, Kakade D. Comparative Evaluation of Sorption, Solubility and Micro-hardness of Heat Cure Polymethylmethacrylate Denture Base Resin \& Flexible Denture Base Resin. $J$ Clin Diagn Res. 2014; 8: ZF01-ZF04

26. Jorge JH, Giampaolo ET, Machado AL, Vergani CE. Cytotoxicity of denture base acrylic resins: a literature review. J Prosthet Dent. 2003; 90: 190-193.

27. Kedjarune U, Charoenworaluk N, Koontongkaew S. Release of methyl methacrylate from heat-cured and autopolymerized resins: cytotoxicity testing related to residual monomer. Aust Dent J. 1999; 44: 25-30.

28. Lefebvre CA, Schuster GS. Biocompatibility of visible light-cured resin systems in prosthodontics. J Prosthet Dent. 1994; 71: 178-185.

29. Jorge JH, Giampaolo ET, Vergani CE, Machado AL, Pavarina AC, Carlos IZ. Effect of post-polymerization heat treatments on the cytotoxicity of two denture base acrylic resins. J Appl Oral Sci. 2006; 14: 203-207.

30. . Ebrahimi Saravi M, Vojdani M, Bahrani F. Evaluation of Cellular Toxicity of Three Denture Base Acrylic Res-ins. J Dent (Tehran) 2012; 9: 180-188.

31. Uzun IH, Tatar A, Hacimuftuoglu A, Saruhan F, Bayindir F. In vitro evaluation of long-term cytotoxic response of injection-molded polyamide and polymethyle metacrylate denture base materials on primary fibroblast cell culture. Acta Odontol Scand. 2013; 71:1267-1272. 